\title{
O AMOR É MAIS FRIO QUE A MORTE: NEGATIVIDADE, INFINITUDE E INDETERMINAÇÃO NA TEORIA HEGELIANA DO DESEJO
}

\author{
Vladimir Safatle* \\ vsafatle@yahoo.com
}

RESUMO Trata-se de mostrar como a experiência de indeterminação que se manifesta fenomenologicamente através das temáticas da angústia e da confrontação com a morte tem papel fundamental para a configuração do processo de reconhecimento na filosofia hegeliana. Levar em conta tal importância pode nos explicar melhor as peculiaridades do conceito hegeliano de individualidade e dos processos de individuação. Isto serve também para compreender o sentido da noção de negatividade e de seus usos na filosofia hegeliana do sujeito, mostrando como ela é imune a certas críticas vindas da filosofia contemporânea.

Palavras-chave Indeterminação;Negatividade;Desejo;Individualidade; Hegel; Morte; Infinitude.

1 Este artigo é o desenvolvimento complementar de outro artigo do autor: "A teoria das pulsões como ontologia negativa" (Revista Discurso, n. 36). Lá, foi questão de mostrar como a teoria psicanalítica das pulsões (em especial em sua versão lacaniana) era solidária de uma reflexão ontológica próxima àquilo que podemos encontrar ao analisarmos os usos hegelianos do conceito de negatividade. Aqui, trata-se de explorar tal via mostrando as relações profundas entre negatividade, universalidade e indeterminação em Hegel.

* Professor do Departamento de Filosofia da Universidade de São Paulo, bolsista de produtividade do CNPq e autor de A paixão do negativo: Lacan e a dialética (Unesp, 2006), Lacan (Publifolha, 2007) e Cinismo e falência da crítica (no prelo). Artigo recebido em dezembro de 2007 e aprovado em março de 2008. 
ABSTRACT The aim of this article is to show how the experience of indetermination has a major role in the development of the process of recognition in hegelian philosophy. This indetermination, which has its phenomenological translation into experiences like anguish and fear of death, can explain some particularities in Hegel's concepts of individuality and individuation. This may help us to understand the meaning of negativity in hegelian philosophy of subject, showing how some contemporary philosophy critics aren't concerned about this concept of negativity.

Keywords Indetermination; Negativity; Desire; Individuality; Hegel; Death; Infinite.

Of course all life is a process of breaking down, but the blows that do the dramatic side of the work [...] don't show their effect all the once.

(Scott Fitzgerald)

\begin{abstract}
Vivemos aliás numa época em que a universalidade do espírito está fortemente consolidada, e a singularidade (Einzelnheit), como convém, tornou-se tanto mais insignificante (gleichgültiger); época em que a universalidade se aferra a toda a sua extensão e riqueza acumulada e as reivindica para si. A parte que cabe à atividade do indivíduo na obra total do espírito só pode ser mínima. Assim, ele deve esquecer-se, como já o implica a natureza da ciência. Na verdade, o indivíduo deve vir-a-ser, e também deve fazer o que lhe for possível; mas não se deve exigir muito dele, já que tampouco pode esperar de si e reclamar para si mesmo. ${ }^{2}$
\end{abstract}

Essas afirmações são importantes por sintetizarem tudo aquilo que várias linhas hegemônicas do pensamento filosófico do século XX imputaram a Hegel. Filósofo da totalidade do Saber Absoluto, incapaz de dar conta da irredutibilidade da diferença e das aspirações de reconhecimento do individual às estratégias de síntese do conceito. Expressão mais bem acabada da crença filosófica de que só seria possível pensar através da articulação de sistemas fortemente hierárquicos, com o conseqüente desprezo pela dignidade ontológica do contingente, deste mesmo contingente que "tampouco pode esperar de si e reclamar para si mesmo". Defesa de uma história na qual o presente apresentaria uma "universalidade do espírito fortemente consolidada", 
história teleológica esvaziada da capacidade em apreender um tempo no qual acontecimentos ainda fossem possíveis. ${ }^{3}$

Em todas essas acusações transparece o que teria sido a impossibilidade hegeliana em dar conta de um particular que não deveria nem poderia ser reduzido à condição de mera particularidade. Como se, em Hegel, o particular fosse apenas a ocasião para a realização concreta do universal, não tendo, com isto, realidade alguma em si. Em todas estas acusações parece ressoar o diagnóstico de Adorno: "Se Hegel tivesse levado a doutrina da identidade entre o universal e o particular até uma dialética no interior do próprio particular, o particular teria recebido tantos direitos quanto o universal. Que este direito - tal como um pai repreendendo seu filho: "Você se crê um ser particular" -, ele o abaixe no nível de simples paixão e psicologize (psychologistisch) o direito da humanidade como se fosse narcisismo, isto não é apenas um pecado original individual do filósofo". " Isto não seria um pecado individual do filósofo porque seria um pecado de todo seu sistema.

Mas podemos nos perguntar sobre a correção de tais interpretações. Hegel teria simplesmente ignorado as exigências necessárias para o reconhecimento da individualidade ou estaria, na verdade, procurando construir as condições para uma recompreensão dos processos de individuação? Estaríamos diante de um traço definidor dos limites da filosofia hegeliana ou esse seria o ponto mais importante de um amplo projeto que visa fornecer um conceito renovado de individualidade em relação ao qual ainda não fomos capazes de nos medir?

Sabemos que Hegel desenvolve seu conceito de individualidade através da noção de consciência-de-si. No entanto, esquecemos com freqüência como a consciência-de-si hegeliana não é um conceito mentalista próprio à reflexividade de uma subjetividade auto-suficiente que se delimita em relação ao que lhe é exterior. Na verdade, consciência-de-si é, para Hegel, um conceito relacional que visa descrever certos modos de imbricação entre sujeito e outro que têm valor constitutivo para a experiência do Si mesmo. Por ser a consciência-de-si um conceito relacional, seus atributos maiores no campo prático (como determinação, autonomia, liberdade e imputabilidade) só podem ser pensados em seu verdadeiro sentido quando abandonamos a crença de que a experiência da ipseidade está assentada na entificação de princípios formais de identidade e unidade. Até porque, a consciência-de-si não se funda na

3 A este respeito, por exemplo, Habermas, falará: "de um espírito que arrasta para dentro do sorvo da sua absoluta auto-referência as diversas contradições atuais apenas para fazê-las perder o seu caráter de realidade, para transformá-las no modus da transparência fantasmagórica de um passado recordado - e para lhes tirar toda a seriedade" (HABERMAS. O discurso filosófico da modernidade, p. 60).

4 ADORNO. Negative Dialektik, p. 323 (tradução modificada). 
apreensão imediata da auto-identidade, mas naquilo que nega sua determinação imanente. Se quisermos utilizar um vocabulário contemporâneo, diremos que a consciência-de-si hegeliana é o locus de uma experiência fundamental de não-identidade que se manifesta através das relações materiais do sujeito ao outro. Relações essas que são pensadas a partir das figuras do trabalho, do desejo e da linguagem.

Mas dizer que a consciência-de-si é um conceito relacional é ainda dizer muito pouco. Pois isto pode simplesmente significar que toda subjetividade é, desde o início, dependente de uma estrutura intersubjetiva de relações que a constitui e a precede. No entanto, parece que Hegel quer dizer algo a mais. Para tanto, precisaremos compreender melhor quem é este outro com o qual me relaciono em experiências constitutivas que se dão no campo do trabalho da linguagem e do desejo. Trata-se apenas de uma outra consciência-de-si ou de uma alteridade mais profunda que está para além do que determina uma individualidade como objeto de representação mental, um para além que me coloca em confrontação com algo que, do ponto de vista da consciência, é indeterminado?

Se seguirmos esta segunda hipótese, talvez compreendamos melhor porque, para Hegel, a individualidade livre (ou seja, aquela individualidade que realizou seu processo de formação) é aquela que leva ao campo da determinação a força disruptiva da confrontação com o indeterminado e que, por isso, tem a capacidade de fragilizar toda aderência limitadora a uma determinidade finita. Talvez seja assim que devamos entender afirmações maiores de Hegel como: "A liberdade não se vincula pois nem ao indeterminado nem ao determinado, mas ela é ambos". ${ }^{5} \mathrm{Ou}$ ainda: "O Eu é a passagem (Übergehen) da indiferenciação indeterminada para a distinção determinada e põe uma determinação como um conteúdo e objeto". ${ }^{6}$ Lembremos que, por ser passagem, o Eu nunca deixa de conservar os momentos que ele coloca em relação através do movimento de passar no oposto. O que nos leva a dizer que ele deve conservar algo do que ainda não é um Eu, algo que é pré-individual.

Esta confrontação com o indeterminado enquanto processo fundamental de constituição da individualidade ficará mais clara se nos perguntarmos pela função de experiências limites como aquelas desempenhadas pela morte e pela angústia no processo de formação da consciência-de-si. Veremos que, longe de serem meros motivos de uma leitura demasiado "existencialista" da fenomenologia hegeliana ou ainda de uma temática moralizadora vinculada 
a um processo de formação ligado ao ressentimento e à resignação diante da finitude (como quer Deleuze e, de uma certa forma, Gerard Lebrun), ${ }^{7}$ a morte e a angústia no caminho de formação da consciência-de-si têm funções lógicas bastante precisas. Pois elas indicam o processo necessário de abertura àquilo que, do ponto de vista da consciência imersa em um regime de pensar marcado pela finitude da representação e dos modos de categorização do entendimento, só pode aparecer como desprovido de determinação. ${ }^{8}$ Neste sentido, não deixa de ser irônico lembrar que a intuição de Kojève a respeito da centralidade da confrontação com a morte no processo de formação da consciência-de-si não era exatamente incorreta. Restava apenas descrever de maneira mais adequada sua função fenomenológica.

Por outro lado, insistir neste aspecto nos permitirá mostrar como, a partir de uma perspectiva hegeliana, o processo de reconhecimento da individualidade não pode estar restrito ao simples reconhecimento da reivindicação de direitos individuais positivos que não encontram posição em situações normativas determinadas, como o quer Honneth ao afirmar não ser possível compreender porque a "antecipação da morte, seja a do próprio sujeito seja a do Outro, deveria conduzir a um reconhecimento da reivindicação de direitos individuais". ${ }^{9}$ O mesmo Honneth para quem a experiência da indeterminação é vivenciada pela consciência basicamente como fonte de sofrimento, como: "um estado torturante de esvaziamento". ${ }^{10}$

De fato, a questão não pode ser respondida se compreendermos o que exige reconhecimento como sendo direitos individuais, expressões singulares da autonomia e da liberdade. Mas não é isto que Hegel tem realmente em vista. Tanto é assim que ele não teme afirmar que o não arriscar a vida pode produzir o reconhecimento enquanto pessoa, mas não enquanto consciência-de-si autônoma e independente. Como se a verdadeira autonomia da consciênciade-si só pudesse ser posta em um terreno para além (ou mesmo para aquém) da forma da pessoa jurídica portadora de diretos positivos e determinações

7 Ver DELEUZE. Nietzsche et la philosophie; assim como LEBRUN. L' envers de la dialectique; ambas leituras que visam, cada uma a sua maneira, confrontar Hegel com temáticas da crítica nietzscheana da moral. Agradeço a Ernani Chaves que me revelou a profunda semelhança estrutural entre a crítica de ambos a Hegel.

8 Não deixa de ser desprovido de interesse lembrar como Deleuze está próximo de Hegel nesta maneira de compreender a morte como potência da indeterminação, o mesmo Deleuze para quem a morte é: "um estado de diferenças livres que não são mais submetidas à forma que lhes era dada por um Eu, que se desenvolve em uma figura que exclui minha própria coerência ao mesmo tempo que a coerência de uma identidade qualquer. Há sempre um 'morre-se' mais profundo do que um 'eu morro'” (DELEUZE.

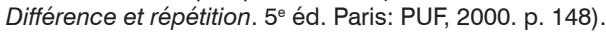

9 HONNETH. Lutte pour reconnaissance, p. 30.

10 HONNETH. Sofrimento da indeterminação, p. 102. 
individualizadoras. Por isso, tudo nos leva a crer que Hegel insiste que se trata de mostrar como a constituição dos sujeitos é solidária da confrontação com algo que só se põe em experiências de negatividade e des-enraizamento que se assemelham à confrontação com o que fragiliza nossos contextos particulares e nossas visões determinadas de mundo. A astúcia de Hegel consistirá em mostrar como o demorar-se diante desta negatividade é condição para a constituição de um pensamento do que pode ter validade universal para os sujeitos.

Sendo assim, as tensões internas à teoria hegeliana do reconhecimento também não podem ser pensadas a partir de dualidades como esta proposta por Habermas ao afirmar:

Eu me compreendo como "pessoa em geral" e como "indivíduo inconfundível" que não se deixa substituir por ninguém em sua biografia. Sou pessoa em geral na medida em que tenho em comum com todas as outras pessoas as propriedades pessoais essenciais de um sujeito que conhece, fala e age. Sou ao mesmo tempo um indivíduo inconfundível, que responde, de maneira insubstituível, por uma biografia tão formadora quanto singular. ${ }^{11}$

Interpretações desta natureza entificam uma noção personalista de individualidade, noção ligada ao Eu como figura de uma determinação completa. Isto nos impede de pensar a fluidez de um conceito de individualidade onde toda determinação seria corroída por um fundo de indeterminação que fragiliza sua identidade e sua fixidez. Por outro lado, tais interpretações tendem a constituir a universalidade como conceito normativo e essencialista ao demarcá-la a partir de um conjunto determinado de "propriedades pessoais essenciais" que não são objetos de questionamento ou conflito, mas motor de toda demanda presente em conflitos sociais. Esta é uma via que nos leva, necessariamente, à substancialização do conceito de sujeito. Como veremos, é exatamente para impedir derivas desta natureza que Hegel insiste tanto na necessidade de o trajeto em direção à universalidade passar pelo "trabalho do negativo" e pelo "caminho do desespero".

\section{Ontogêneses e conflitos}

Se reconstruirmos o dispositivo fundamental de desenvolvimento da teoria hegeliana da formação da consciência-de-si, veremos que se trata de partir de considerações sobre a ontogênese das capacidades prático- 
cognitivas dos sujeitos, uma ontogênese que se desenvolve através de processos de socialização e de individuação. Trata-se de se perguntar sobre a gênese empírica de nossas habilidades cognitivas e de nossos esquemas de determinação racional da ação. No entanto, em vez de partir da análise das práticas de socialização através de identificações que ocorrem em núcleos elementares de interação social (família, sociedade civil, instituições, Estado), Hegel prefere, inicialmente, fornecer algo como uma matriz fenomenológica geral para a inteligibilidade de tais processos. Trata-se da dialética do Senhor e do Escravo (DSE).

Conhecemos tentativas contemporâneas de invalidaro papel central daDSE na reflexão sobre os processos de formação e reconhecimento da consciênciade-si. Robert Williams dirá, por exemplo: "Não é o processo completo de reconhecimento recíproco, mas o fracasso em realizar tal reconhecimento que será enfatizado. Por esta razão, a figura do Senhor/Escravo tende a dominar o relato sobre a intersubjetividade na Fenomenologia". ${ }^{12}$ Apenas no seu sistema de maturidade Hegel teria enfim fornecido todo este "processo completo". Mas leituras desta natureza tendem a esquecer como a Fenomenologia já é a versão completa do sistema a partir do ponto de vista da consciência, assim como a Ciência da Lógica é a versão completa do sistema a partir do ponto de vista do saber objetivo. Neste sentido, nunca é prudente relativizar o que a Fenomenologia nos traz, como se tratasse de processos incompletos.

$\mathrm{Na}$ verdade, o desconforto de vários comentadores hegelianos com a DSE vem principalmente do fato de ela nos mostrar como os processos de reconhecimento social são mediados por um desejo que instaura o conflito enquanto solo ontológico, por se apresentar desde o início como aquilo que constitui relações apenas a partir de dinâmicas de dominação e servidão. Através do desejo, procuro submeter o outro à condição de objeto desprovido de autonomia, outro cuja essência consiste apenas em ser suporte do meu desejo. Mas como o desejo é o primeiro modo de relação ao outro, então o conflito que ele instaura tem o peso de um dado ontológico para o modo de ser da consciência-de-si.

No entanto, se assim for, parece haver um equívoco neste esquema hegeliano. Pois: "De acordo com Hegel, o processo de reconhecimento começa com o fato de o Eu estar fora de si, de ele estar cancelado como ser-para-si e intuir si-mesmo apenas no outro. No entanto, esta não é uma estrutura de luta, 
mas do amor". ${ }^{13}$ Um conflito com o outro só faz sentido por pressupor que o outro deve e é capaz de me reconhecer. Se acreditasse que o outro não é capaz (por ser, por exemplo, louco) ou não deve me reconhecer (por ser, por exemplo, alguém que desprezo), então não haveria demanda de reconhecimento, não haveria tentativa de submeter o sistema de interesses do outro ao meu desejo. Mas se creio que o outro deve e é capaz de me reconhecer, é porque há um tipo prévio de vínculo que poderíamos chamar de "amor" e que serve aqui como base intersubjetiva inicial e não problemática de relações. Assim, Hegel deveria ter começado a descrição dos processos conflituais de reconhecimento entre sujeitos a partir da apresentação do amor como fundamento e base normativa das demandas sociais de reconhecimento presentes em processos de interação. Algo que, por sinal, ele faz em seus textos de juventude, como na Filosofia do espírito, de 1805.

Retomar a DSE, entretanto, pode nos explicar porque Hegel não tem como concordar com tentativas contemporâneas de recuperar o amor como "estrutura geral de reconhecimento recíproco" 14 que deveria ser pressuposta como solo intersubjetivo primário para o desenvolvimento seguro e normatizado de todo e qualquer processo de determinação social da individualidade. Isto ao menos se pensarmos o amor a partir do paradigma comunicacional de relações de mútua dependência e complementaridade. Pois, ao contrário, talvez Hegel queira mostrar que os processos de interação e socialização são mediados por um desejo cuja opacidade e negatividade problematiza de maneira decisiva a intersubjetividade primária do amor. ${ }^{15}$ Desejo que só poderá ser satisfeito ao reconhecer-se em uma individualidade onde o Eu sempre vai estar, de uma certa forma, irredutivelmente fora de si; desejo cuja satisfação nos leva, inclusive, ao abandono do Eu como forma altamente individuada.

É certo que o desejo enquanto relação negativa para com o objeto exige ser superado. No entanto, tal superação não implica recuperar alguma forma de interação recíproca entre sujeitos fortemente individualizados e determinados,

13 SIEP. Der Kampf um Anerkennung. Zur Auseinandersetzung Hegels mit Hobbes in den Jenaer Schriften. In: Hegel-Studien, p. 194.

14 HABERMAS. Verdade e justificação, p. 200. Sendo que a mais justamente conhecida e sistemática destas tentativas é aquela empreendida por Axel Honneth em seu Luta por reconhecimento (op. cit.).

15 Lembremos que a Fenomenologia do Espírito apresenta uma crítica explícita ao amor como princípio de relações intersubjetivas através da figura do "Prazer e da necessidade". Aqui, encontramos também a exigência de: "sich als diese Eizelne in einem andern oder ein anderes Selbstbewustssein als sich auzuschauen". No entanto, tal intuição só pode se realizar através da submissão do outro à essência negativa de um gozo que em nada se aquieta. Não se trata de fazer alguma confusão entre 'amor' e 'gozo', mas de lembrar que a tematização hegeliana do hedonismo pode nos fornecer um modelo para questionarmos a possibilidade de realização social de um conceito de amor fundado no paradigma comunicacional de relações de mútua dependência e complementaridade. 
muito menos procurar pôr processos de indiferenciação simbiótica prépessoais como horizonte de desenvolvimento de relações sociais. Como gostaria de mostrar, a experiência da negatividade do desejo será, de certa maneira, conservada como base para a reconstrução dos modos de relação a si e ao outro. Isto obrigará, no limite, à problematização de todo conceito de amor ligado a formas de paradigmas comunicacionais. ${ }^{16}$

Se voltarmos ao texto da Fenomenologia, veremos que o desejo aparece pela primeira vez em um contexto esclarecedor. Trata-se de uma discussão a respeito das condições para a realização da unidade entre consciência-de-si e consciência de objeto. Ao lembrar que a noção de "fenômeno", enquanto "diferença que não tem em si nenhum ser" (já que é apenas o aparecer paraum-Outro) não era figura da unidade da consciência-de-si consigo mesma, mas, ao contrário, era a própria clivagem (já que a essencialidade está sempre em um Outro inacessível ao saber: a coisa-em-si), Hegel afirma: "Essa unidade [da consciência-de-si] deve vir-a-ser essencial a ela, o que significa: a consciência-de-si é desejo em geral (Begierde überhaupt)" ${ }^{17}$

$\mathrm{O}$ que significa esta introdução do que Hegel chama aqui de "desejo em geral", ou seja, não desejo deste ou daquele objeto, mas desejo tomado em seu sentido geral, como modo de relação entre sujeito e objeto? A partir do contexto, podemos compreender que a unidade da consciência-de-si com o que havia se alojado no "interior das Coisas" como essência para além dos fenômenos, unidade entre o saber e a determinação essencial dos objetos, só será possível a partir do momento em que compreendermos as relações entre sujeito e objeto não apenas como relações de conhecimento, mas primeiramente como relações de desejo e satisfação.

A princípio, uma afirmação desta natureza parece algo totalmente temerário. Estaria Hegel colocando em marcha alguma forma de psicologismo selvagem que submete as expectativas cognitivas a interesses práticofinalistas? Ou estaria ele insistindo, e aí na melhor tradição que encontramos também em Nietzsche e Freud, que a razão configura seus procedimentos (ou seja, ela define o que é racional e legítimo) através dos interesses postos na realização de fins práticos, interesses que nos levam a recuperar a dignidade filosófica da categoria de "desejo"?

16 Isto pode nos explicar porque alguém como Jacques Lacan, leitor precoce da DSE, desenvolverá um conceito de amor que não pode mais ser compreendido como figura de uma intersubjetividade primária, mas que exige a mobilização de conceitos como "destituição subjetiva". A este respeito, remeto ao meu SAFATLE. A paixão do negativo, p. 209-220. Talvez este seria o único caminho para recuperar um conceito de amor que faça jus à experiência hegeliana de negatividade.

17 HEGEL. Fenomenologia do Espírito, p. 120. 
De fato, esta segunda alternativa parece ser o caso. Neste sentido, podemos seguir um comentador que viu isto claramente, Robert Pippin: "Hegel parece estar dizendo que o problema da objetividade, do que estamos dispostos a contar como uma reivindicação objetiva é o problema de satisfação do desejo, que a 'verdade' é totalmente relativizada por fins pragmáticos [...] Tudo se passa como se Hegel estivesse reivindicando, como muitos fizeram nos séculos XIX e XX, que o que conta como explicações bem-sucedidas dependem de quais problemas práticos queremos resolver [...] que o conhecimento é uma função de interesses humanos". ${ }^{18}$

No entanto, parece que Hegel estaria assim entrando com os dois pés em alguma forma de relativismo que submete expectativas universalizantes de verdade à contingência de contextos marcados por interesses e desejos particulares. A não ser que Hegel seja capaz de mostrar que os interesses práticos não são guiados pelo particularismo de apetites e inclinações, mas que, ao se engajar na dimensão prática tendo em vista a satisfação de seus desejos, os sujeitos realizam necessariamente as aspirações universalizantes da razão. Lembremos ainda que, por não admitir distinções estritas entre empírico e transcendental, Hegel não está disposto a operar rupturas entre desejo patológico e vontade livre cujo reconhecimento seria o fundamento para a constituição do universo dos direitos. Há algo da universalidade da vontade livre que já se manifesta no interior do desejo.

Colocações desta natureza parecem ir na contramão de tendências hegemônicas do pensamento crítico do século XX. Basta lembrar, por exemplo, desta questão sempre posta por teóricos da Escola de Frankfurt, questão animada pela psicanálise freudiana com sua descrição da natureza conflitual dos processos de socialização no interior da família e de internalização da Lei social: o que é necessário perder para se conformar às exigências de racionalidade e universalidade presentes em processos hegemônicos de socialização do desejo? Ou ainda: qual é o preço a pagar a fim de viabilizar tais exigências? Quanto devemos pagar para sustentar afirmações como: "A verdadeira liberdade é, enquanto eticidade, o fato de a vontade não ter finalidades subjetivas, ou seja, egoístas, mas um conteúdo universal"? ${ }^{19}$ Como disse Adorno, não estaríamos aí diante da tentativa de "psicologizar o direito da humanidade como se fosse narcisismo"?

Tais questões têm conseqüências maiores. Tomemos, por exemplo, o caso de Adorno, para quem os modos de organização da realidade no capitalismo 
avançado, assim como os regimes de funcionamento de suas dinâmicas de interação social, de seus núcleos de socialização, eram dependentes da implementação de uma metafísica da identidade. Uma metafísica que guiaria a ontogênese das capacidades prático-cognitivas dos sujeitos através da internalização de exigências de unidade que orientam a formação do Eu e reprimem o que é da ordem do corpo, das pulsões e da sexualidade (em suma, do desejo). Assim, se Adorno pode dizer que: "identidade de si e alienação de si estão juntas desde o início", ${ }^{20}$ é principalmente porque a socialização que visa constituir individualidades segue a lógica da internalização de uma Lei repressiva da identidade. Daí afirmações como: "A consciência nascente da liberdade alimenta-se da memória (Erinnerung) do impulso (Impuls) arcaico, não ainda guiado por um Eu sólido. Quanto mais o Eu restringe (zügeln) tal impulso, mais a liberdade primitiva (vorzeitlich) lhe parece suspeita pois caótica". ${ }^{21}$ Afirmações que demonstram como análise da realidade social, crítica da metafísica da identidade e crítica da ontogênese das capacidades prático-cognitivas estariam absolutamente vinculadas. Um vínculo que legitimaria Adorno a voltar-se contra Hegel, o mesmo Hegel que não teria compreendido que a violência do Universal realizando-se não é idêntica à essência dos indivíduos, mas contrária.

No entanto, devemos insistir que Hegel é sensível àquilo que não se determinaintegralmentede maneirapositiva através deprocessos de socialização e individuação. Ele sabe que há um caminho complexo até a realização da possibilidade de tais processos preencherem exigências universalizantes. Por isso, em Hegel, a ontogênese do sujeito é o reconhecimento de uma anterioridade ontológica do conflito que se manifesta nesta ligação necessária entre subjetividade e negatividade.

Sobre tal anterioridade ontológica, lembremos como Hegel chega a "naturalizar a noção de conflito" através de sua filosofia da natureza, isto ao instaurá-lo no interior de seu conceito de "vida". Vida cujo movimento será recuperado de maneira reflexiva no interior da determinação da consciênciade-si. Ou seja, vida que fornecerá o modelo do processo reflexivo de autoposição próprio à consciência-de-si. Insistir nesta complementaridade é inclusive maneira de lembrar que aquilo que se manifesta inicialmente como exterioridade em relação à consciência-de-si (a natureza, a mesma na qual Adorno verá o signo da emancipação do sujeito através da suspensão de sua 
dominação pela razão) fornecerá o modelo de constituição do conceito de individualidade.

\section{A fluidez absoluta da vida}

Sabemos como, para a geração de Hegel, a filosofia moderna deveria ultrapassar um sistema de dicotomias que encontrara sua figura mais bem acabada na maneira kantiana de definir o primado da faculdade do entendimento na orientação da capacidade cognitiva da consciência. Hegel partilha o diagnóstico de pós-kantianos como Fichte e Schelling para quem, na filosofia kantiana, o primado da reflexão e do entendimento produziu cisões irreparáveis. Daí porque "o único interesse da razão é o de suspender antíteses rígidas", ${ }^{22}$ como aquelas que orientam as distinções entre sujeito e objeto, forma e matéria, receptividade e espontaneidade, natureza e subjetividade.

Em Hegel, uma das primeiras maneiras de definir o modo de anulação de tais dicotomias foi a tematização de uma espécie de solo comum, de fundamento primeiro, a partir do qual sujeito e objeto se extrairiam, na mais clara tradição schellinguiana. Este fundamento primeiro era a vida. Daí porque Hegel poderá afirmar, na juventude: "Pensar a pura vida, eis a tarefa", já que "A consciência desta pura vida seria a consciência do que o homem é". ${ }^{23}$ Neste sentido, ter a vida por objeto do desejo é reconhecer, no próprio objeto, a substância que forma consciências-de-si. Não é por outra razão que Hegel apresenta a vida logo na entrada da seção dedicada à consciência-de-si, na Fenomenologia do Espírito. Enquanto consciência que reconhece as dicotomias nas quais uma razão compreendida a partir da confrontação entre sujeito e objeto se enredara, a consciência-de-si procura um background normativo intersubjetivamente partilhado a partir do qual todos os modos de interação entre sujeito e objeto se extraem. A vida aparece inicialmente como este background.

No entanto, a vida é ainda uma figura incompleta porque seu movimento não é para-si, ou seja, não é reflexivamente posto e apreendido. Não se trata aqui de simplesmente negar, através de uma negação simples, o que a reflexão sobre a vida traz. De fato, há uma certa continuidade entre a vida

22 HEGEL. Diferença dos sistemas filosóficos de Fichte e Schelling, p. 38.

23 Como bem viu Hyppolite: "a pura vida supera essa separação [produzida pelo primado do entendimento] ou tal aparência de separação; é a unidade concreta que o Hegel dos trabalhos de juventude ainda não consegue exprimir sob forma dialética" (HYPPOLITE. Gênese e estrutura da Fenomenologia do Espírito, p. 162). Ou ainda: "Contra a encarnação autoritária da razão centrada no sujeito, Hegel apresenta o poder unificador de uma intersubjetividade que se manifesta sob o título de amor e vida" (HABERMAS. $O$ discurso filosófico da modernidade, p. 39). 
e a consciência-de-si claramente posta por Hegel nos seguintes termos: "A consciência-de-si é a unidade para a qual é a infinita unidade das diferenças, mas a vida é apenas essa unidade mesma, de tal forma que não é ao mesmo tempo para si mesma". ${ }^{24}$ Ou seja, a diferença entre consciência-de-si e vida é afirmada sobre um fundo de semelhanças.

Mas como Hegel compreende a vida e seu movimento, seu ciclo? De maneira esquemática, podemos dizer que a vida é fundamentalmente compreendida a partir da tensão entre a universalidade da substância que define o vivente e a particularidade do indivíduo ou da multiplicidade diferenciadora das formas viventes (espécies). Esta tensão entre unidade e indivíduo produz uma forma de oposição que Hegel havia chamado, em Diferença sobre os sistemas de Fichte e Schelling, de "o fator da vida" (Faktor des Lebens), para descrever o motor de um movimento no interior da vida que visa a superação de tal oposição. Por tender em direção a esta superação, a vida pode aparecer como primeira figura da infinitude. Isto nos explica porque Hegel havia dito, ao apresentar o conceito de infinitude no capítulo sobre o entendimento, na Fenomenologia do espírito: "Essa infinitude simples - ou o conceito absoluto - deve-se chamar a essência simples da vida, a lama do mundo, o sangue universal". ${ }^{25}$ Hegel descreve assim o ciclo da vida:

Seu ciclo se encerra nos momentos seguintes. A essência é a infinitude, como ser-
superado de todas as diferenças [a vida é o que retorna sempre a si na multiplicidade
de diferenças do vivente], o puro movimento de rotação, a quietude de si mesma como
infinitude absolutamente inquieta, a independência mesma em que se dissolvem as
diferenças do movimento; a essência simples do tempo que tem, nessa igualdade-
consigo-mesma, a figura sólida do espaço. Porém, nesse meio simples e universal,
as diferenças também estão como diferenças, pois essa fluidez universal (allgemeine
Flüssigkeit) [da vida como unidade] só possui sua natureza negativa enquanto é
um superar das mesmas, mas não pode superar as diferenças se essas não têm um
subsistir. ${ }^{26}$

Este ciclo demonstra como há uma cisão (Entzweiung) no interior da vida. Hegel chega a falar que a vida conhece apenas uma unidade negativa absoluta (absolut negative Einheit) consigo mesma. Isto significa que, por um lado, ela é substância universal que passa por todos os viventes. Daí o uso importante de uma metáfora como "fluidez" que indica o que não pode se estabilizar em uma determinidade fixa, o que tendencialmente se manifesta como princípio 
de indeterminação. Mas, por outro, ela é tendência a diferenciações cada vez mais visíveis que recebem formas independentes (selbstständigen Gestalten) cada vez mais determinadas. Como vemos, há um conflito interno à vida entre indeterminação e determinação. Conflito que faz com que a posição da individualidade seja a divisão de uma fluidez indiferenciada (unterschiedslosen Flüssigkeit) que, por sua vez, só pode ser posta através da dissolução da própria individualidade. É pensando em tal conflito que Hegel dirá:

A inadequação (Unangemessenheit) do animal à universalidade [da vida] é sua doença original e o germe interno de sua morte. A superação desta inadequação é ela mesma a execução deste destino [...] [já que] na natureza, a universalidade só acede ao fenômeno desta maneira negativa que consiste em superar a subjetividade. ${ }^{27}$

Hegel quer insistir que, na natureza, a vida só pode alcançar a universalidade, esta fluidez fundamental, através da dissolução da individualidade, daí porque o organismo morre de uma causa interna, ele não pode se reconciliar com a universalidade. É por não ser capaz de reconciliar a individualidade com o universal que a natureza é uma figura imperfeita do Espírito. Ela chega a desenvolver uma certa reconciliação, ela também imperfeita: o gênero (Gattung). Mas, do ponto de vista do gênero, todos os indivíduos já estão mortos. Ou seja, a assunção de si como gênero apenas é uma reconciliação que, mais uma vez, opera uma negação simples da individualidade. Daí porque: "O objetivo da natureza é matar-se a si mesma e quebrar sua casca, esta do imediato, do sensível, queimar-se como fênix para emergir desta exterioridade rejuvenescida como espírito". ${ }^{28} \mathrm{O}$ que leva Hegel a afirmar, ao final, que a vida: "é o todo que se desenvolve, que dissolve seu desenvolvimento e que se conserva simples nesse movimento". ${ }^{29}$

Podemos mesmo dizer que a consciência-de-si será capaz de experimentar este conflito presente no interior da vida, mas sem se dissolver como individualidade. Ela terá a experiência da universalidade negativa, da fluidez absoluta, mas tal experiência será um tremor diante da morte que terá função formadora. No entanto, está é uma maneira mais nebulosa de dizer que o movimento próprio à consciência-de-si já está, de certa forma, presente na natureza. Um pouco como se o movimento que anima o meio no qual a consciência-de-si age (a história) já estivesse em germe na natureza. $\mathrm{O}$ que não poderia ser diferente para alguém que afirmou: “O espírito proveio 
(hervorgegangen) da natureza". ${ }^{30}$ Um provir que não o impede de dizer que o espírito estava, de certo modo, antes da natureza (já que ele se confunde com seu movimento).

De maneira peculiar, Hegel está dizendo que entre natureza e história não há uma completa ruptura, há apenas o aprofundamento reflexivo de um movimento partilhado, o que complexifica as dicotomias modernas entre natureza e liberdade. ${ }^{31}$ Movimento marcado principalmente pelas noções de conflito e de luta. Não uma luta darwiniana entre espécies, mas uma luta no interior de cada individualidade biológica, no interior de cada singularidade natural, entre determinação e indeterminação. ${ }^{32}$ Todo o esforço de Hegel consiste em mostrar como a singularidade natural já é, desde sempre, campo de trabalho do negativo, e não realidade que se determina de maneira imanente. Por isso, a superação da singularidade natural é, no fundo, a realização "natural" de seu destino.

Isto pode nos ajudar a compreender porque o movimento do Espírito parece seguir de perto esta dissolução das determinidades e manifestação da fluidez que anima a natureza, já que o Espírito é tanto sua inscrição em uma figura finita quanto o desaparecimento incessante de tal figuração. ${ }^{33}$ Gerard Lebrun percebeu claramente esta natureza do Espírito ao afirmar: "Se somos assegurados de que o progresso não é repetitivo, mas explicitador, é porque o Espírito não se produz produzindo suas formações finitas mas, ao contrário, em recusando-as uma após outra. Não é a potência dos impérios, mas sua morte que dá à História 'razão"”. Ou ainda: "O único tipo de devir que o movimento do Conceito esposa nada tem em comum com a transição indiferente de uma

30 HEGEL. Enciclopédia. v. 1, § 376.

31 Neste sentido, não é possível aceitar de maneira completa afirmações como: "a realização da liberdade ocorre quando a natureza (aqui, a sociedade que teve início numa forma tosca e primitiva) é remodelada segundo as demandas da razão" (TAYLOR. Hegel e a sociedade moderna, p. 108). De certo modo, poderíamos mesmo dizer o inverso: a fluidez absoluta da natureza oferece a base para a remodelação da razão e de sua inquietude. Insistir em "remodelagem" é apenas uma maneira mais cuidadosa de continuar pensando a relação entre natureza e história a partir de uma certa ruptura que retira toda dignidade ontológica da primeira. Melhor seria dizer, como Malabou, que: "a passagem da natureza ao espírito não se produz como uma ultrapassagem, mas como duplicação (redoublement), processo através do qual o espírito se constitui como segunda natureza. Esta duplicação reflexiva é, de uma certa forma, o 'estádio do espelho' do espírito, no qual se constitui a primeira forma de sua identidade" (MALABOU. L'avenir de Hegel, p. 43).

32 À sua maneira, encontraremos o mesmo tipo de conflito entre determinação e indeterminação nas individualidades biológicas em Freud através de sua teoria das pulsões de vida e de morte, teoria que, por dar conta de processos que se situam no limite entre o somático e o psíquico, também se refere tanto à natureza quanto à história.

33 O que não poderia ser diferente se aceitarmos que: "O processo dialético é plástico na medida em que articula no seu curso a imobilidade plena (a fixidez), a vacuidade (a dissolução) e a vitalidade do todo como reconciliação destes dois extremos, conjugação da resistência (Widerstand) e da fluidez (Flüssigkeit)" (MALABOU. L'avenir de Hegel, p. 26). 
forma à outra. Ele só pode ser um devir que sanciona a instabilidade da figura que vem de ser transgredida, um devir expressamente nadificador". ${ }^{34}$ Por sinal, não é por outra razão que tanto a vida quanto o espírito serão animados pela mesma "fluidez universal", pela mesma "inquietude" (Unruhe).

Por fim, devemos dizer que esta tensão no interior das individualidades biológicas aparecerá de maneira reflexiva no movimento de reconhecimento que orienta processos de socialização e individuação. O que nos explica porque, no texto da Fenomenologia, as considerações sobre a estrutura das dinâmicas sociais de reconhecimento são antecedidas pela descrição do ciclo da vida. Se a vida é o primeiro objeto do desejo da consciência-de-si, é porque a verdade do desejo, sua satisfação, só pode se dar lá onde ele se confrontar com um objeto marcado pela fluidez universal. Ou seja, se a verdade do desejo é realizar as aspirações universalizantes da razão, é porque convergem para a noção hegeliana de universal experiências de indeterminação. Neste sentido, voltemos os olhos para o desejo hegeliano.

\section{O que realmente falta ao desejo?}

Para Hegel, o desejo (Begierde) é a maneira através da qual a consciênciade-si aparece em seu primeiro grau de desenvolvimento. Neste sentido, ele é, ao mesmo tempo, modo de interação social e modo de relação ao objeto. Além do desejo, Hegel apresenta, ao menos, outros dois operadores reflexivos de determinação da consciência-de-si: o trabalho e a linguagem. Estes três operadores tecem entre si articulações profundas, já que o trabalho é “desejo refreado" e a linguagem obedece à mesma dinâmica de relação à expressão que o trabalho.

Lembremos inicialmente como Hegel parece vincular-se a uma longa tradição que remonta a Platão e compreende o desejo como manifestação da falta. Vejamos, por exemplo, um trecho maior da Enciclopédia. Lá, ao falar sobre o desejo, Hegel afirma:

O sujeito intui no objeto sua própria falta (Mangel), sua própria unilateralidade - ele vê no objeto algo que pertence à sua própria essência e que, no entanto, lhe falta. A consciência-de-si pode suprimir esta contradição por não ser um ser, mas uma atividade absoluta. ${ }^{35}$ 
A colocação não poderia ser mais clara. O que move o desejo é a falta que aparece intuída no objeto. Um objeto que, por isso, pode se pôr como aquilo que determina a essencialidade do sujeito. Ter a sua essência em um outro (o objeto) é uma contradição que a consciência pode suprimir por não ser exatamente um ser, mas uma atividade, isto no sentido de ser uma reflexão que, por ser posicional, toma a si mesma por objeto e, neste mesmo movimento, assimila o objeto a si. Esta experiência da falta é tão central para Hegel que ele chega a definir a especificidade do vivente (Lebendiges) através da sua capacidade em sentir falta, em sentir esta excitação (Erregung) que o leva à necessidade do movimento; assim como ele definirá o sujeito como aquele que tem a capacidade de suportar (ertragen) a contradição de si mesmo (Widerspruch seiner selbst) produzida por um desejo que coloca a essência do sujeito no objeto. Hegel acredita que a falta é tão definidora da condição de sujeito que ele chega a afirmar:

A falta da cadeira, quando ela tem três pés, está em nós [pois é falta em relação ao conceito de cadeira]; mas a própria falta está na vida, já que a vida a conhece como limitação, ainda que ela também esteja superada. É pois um privilégio das naturezas superiores sentir dor; quanto mais elevada a natureza, mais infeliz ela se sente. Os grandes homens têm uma grande necessidade e o impulso (Trieb) a superála. Grandes ações vêm apenas de profunda dor da alma (Gemütes); a origem do mal etc. tem aqui sua dissolução. ${ }^{36}$

Mas dizer isto é ainda dizer muito pouco. Pois se o desejo é falta e o objeto aparece como a determinação essencial desta falta, então deveríamos dizer que, na consumação do objeto, a consciência encontra sua satisfação. No entanto, não é isto o que ocorre:

O desejo e a certeza de si mesma alcançada na satisfação do desejo [notemos esta articulação fundamental: a certeza de si mesmo é estritamente vinculada aos modos de satisfação do desejo] são condicionados pelo objeto, pois a satisfação ocorre através do suprimir desse Outro, para que haja suprimir, esse Outro deve ser. A consciência-de-si não pode assim suprimir o objeto através de sua relação negativa para com ele, pois essa relação antes reproduz o objeto, assim como o desejo. ${ }^{37}$

A contradição encontra-se aqui na seguinte operação: o desejo não é apenas uma função intencional ligada à satisfação da necessidade animal, como se a falta fosse vinculada à positividade de um objeto natural. Ele é operação de autoposição da consciência: através do desejo a consciência procura se 
intuir no objeto, tomar a si mesma como objeto e este é o verdadeiro motor da satisfação. Através do desejo, na verdade, a consciência procura a si mesma. Até porque, devemos ter clareza a este respeito, a falta é um modo de ser da consciência, modo de ser de uma consciência que insiste que as determinações estão sempre em falta em relação ao ser.

Como sabemos, esta proposição do desejo como falta foi, nas últimas décadas, objeto de críticas virulentas vindas principalmente de autores como Gilles Deleuze e Félix Guattari. Seu alvo não era apenas a apropriação do conceito hegeliano feita pela psicanálise lacaniana, mas também a metafísica da negatividade presente no conceito hegeliano de desejo. Pois a maneira com que a psicanálise procura socializar o desejo produziria um desejo marcado pela negatividade, pela perda, pelo conflito, desejo como falta que nos remete, afinal de contas, a Hegel. No entanto, "Nada falta ao desejo", dirão os dois, "ele não está em falta em relação ao seu objeto. Na verdade, é o sujeito que está em falta com o desejo, ou é ao desejo que falta sujeito fixo; só há sujeito fixo graças à repressão". ${ }^{38}$ Neste caso, tratava-se de insistir que a afirmação do desejo como falta não poderia ser outra coisa que fruto de uma ilusão metafísica a respeito da realidade do negativo. Ilusão animada por uma teologia negativa que sequer tem medo de dizer seu nome.

A este respeito, lembremos que há três maneiras de compreender a proposição de que a essência do desejo é falta. Primeiro, a falta pode ser simples manifestação da carência, da privação de um objeto determinado da necessidade. Esta claramente não é a posição hegeliana, já que implicaria uma naturalização de sistemas de necessidades estranha a uma filosofia que não compreende a natureza como sistema fechado de leis.

Segundo, podemos dizer que a falta é um modo de ser da consciência porque ela indica a transcendência do desejo em relação aos objetos empíricos, seguindo aqui uma via aberta por Platão.

Sabemos como Platão faz Sócrates afirmar, em O banquete: "Desejamos aquilo do qual somos desprovidos" 39 ou aquilo que não está presente ou aquilo que pessoalmente não sou. Daí porque Eros é o intermediário entre dois contrários: ele manifesta a falta de coisas belas e boas que impelem o desejo (epithumia), coisas a respeito das quais tenho um certo saber. Ou seja, o objeto do desejo é aquilo que, ao mesmo tempo, não tenho e está em mim. Este caráter intermediário entre presença e ausência fica visível a partir do 
momento em que Eros é compreendido através da perspectiva do amante (erastes), e não do amado (eromenos).

No entanto, esta falta que mobiliza o desejo não está exatamente ligada à dimensão dos objetos sensíveis. Pois: "a beleza que existe em tal ou tal corpo é irmã da beleza que reside em outro e, se devemos perseguir o belo em sua forma sensível, seria uma insígnia desrazão não julgar una e idêntica a beleza que reside em todos os corpos". ${ }^{40}$ Esta desqualificação do sensível permite a abertura a uma série de asceses que nos levará à "essência mesma do belo" para além do que é mortal e corruptível. Uma essência cuja visão implicaria liberar o belo em sua pureza, abrir espaço para sua manifestação sem misturas na unicidade de sua natureza formal. Poderíamos mesmo afirmar que, nesta ascese: "a pessoa deixa sua particularidade para trás", ${ }^{41}$ como se fosse questão de negar a essencialidade do que é da ordem da natureza mortal, isto em prol da essencialidade de algo que: "de alguma forma lhe pertence, mas que não the é imediatamente disponível". ${ }^{42}$ Assim, a negatividade do desejo seria, no fundo, manifestação intencional da transcendência inesgotável do ser em relação à empiricidade.

É pensando nesta vertente que Deleuze e Guattari desenvolvem sua crítica ao desejo como falta. Tudo se passaria como se Hegel se apropriasse deste esquema de transcendência para colocá-lo em operação no interior de uma certa teologia negativa onde não é mais a transcendência da Idéia que produz a desqualificação de todo sensível, mas a "pura negatividade" que só aparece através da reiteração infinita da ultrapassagem da determinação finita sensível, do sacrifício infinito de uma determinação finita que precisa continuar a desaparecer, permanecer desaparecendo, a fim de que a negatividade tenha realidade.

No entanto, podemos dizer que não é essa a questão que está em jogo na definição hegeliana do desejo em sua negatividade. Pois a negatividade do desejo não vem exatamente da pressão negadora da transcendência, como queria alguém como Kojève (no fundo, a referência maior de Deleuze em sua leitura de Hegel). ${ }^{43}$ Por sinal, este apelo irrestrito à transcendência seria estranho para um autor, como Hegel, que compreende o saber absoluto como

40 Idem, 210b.

41 LEAR. Eros and Unknowing: the psychoanalytic significance of Plato's Symposium. In: Open minded, p. 163. Esta desqualificação do sensível e da particularidade leva Lebrun a afirmar que: "o adestramento socrático submete o indivíduo a uma autoridade que é apenas a negação simples de todas as pulsões" (LEBRUN. L'envers de la dialectique, p. 128).

42 MORTLEY. Désir et différence dans la tradition platonicienne, p. 81.

43 Como lembrou muito bem Paulo Arantes em ARANTES. Um Hegel errado mas vivo. Revista Ide. 
reconciliação com uma dimensão renovada do empírico. A este respeito, basta lembrar como, ao falar sobre a reconciliação produzida pelo saber absoluto, Hegel apresenta um julgamento infinito (unendlichen Urteil) capaz de produzir a síntese da cisão entre sujeito e objeto. Trata-se da afirmação: "o ser do eu é uma coisa (das Sein des Ich ein Ding ist); e precisamente uma coisa sensível e imediata (ein sinnliches unmittelbares Ding)". Dessa afirmação, segue-se um comentário: "Este julgamento, tomado assim como imediatamente soa, é carente-de-espírito, ou melhor, é a própria carência-de-espírito", pois, se compreendemos a coisa sensível como uma predicação simples do eu, então o eu desaparece na empiricidade da coisa - o predicado põe o sujeito: "mas quanto ao seu conceito, é de fato o mais rico-de-espírito". ${ }^{44}$ Pois seu conceito nos leva a uma recompreensão da dimensão do sensível para além da sua domesticação pelas estruturas identitárias e finitas da estética transcendental.

$\mathrm{Na}$ verdade, para entender o que Hegel tem em vista na sua noção de desejo como falta, não devemos compreender a falta como privação, como carência ou simplesmente como transcendência, mas como manifestação da infinitude. Esta infinitude pode ser ruim, se a satisfação do desejo for vista como consumo reiterado de objetos que produzem um gozo (Genuss) que é apenas submissão narcísica (ou "egoísta", se quisermos usar um termo hegeliano) do outro ao Eu. Mas ela será infinitude verdadeira quando se confrontar com objetos liberados de determinações finitas.

Lembremos inicialmente que, para Hegel, a falta aparece como modo de ser da consciência em um contexto histórico preciso. Contexto marcado pela problematização do que serve de fundamento às formas de vida da modernidade. Hegel compreende a modernidade como o momento histórico no qual o espírito "perdeu" a imediatez da sua vida substancial, ou seja, nada the aparece mais como substancialmente fundamentado em um poder capaz de unificar as várias esferas sociais de valores. ${ }^{45}$ Daí diagnósticos clássicos de época como: "[Nos tempos modernos] Não somente está perdida para

44 HEGEL. Fenomenologia do Espírito, p. 209.

45 De fato, esta perda deve ser posta entre parênteses porque, de certa maneira, a consciência perdeu aquilo que ela nunca teve. Por isso, Hegel pode afirmar, a respeito da eticidade: "Mas a consciência-de-si que de início só era espírito imediatamente e segundo o conceito saiu (herausgetreten) dessa felicidade que consiste em ter alcançado seu destino e em viver nele, ou então: ainda não alcançou sua felicidade. Pode-se dizer igualmente uma coisa ou outra. A razão precisa (muss) sair dessa felicidade, pois somente em si, ou imediatamente a vida de um povo livre é a eticidade real" (HEGEL. Fenomenologia do Espírito, op. cit., p. 224). Ou seja, o que Hegel diz é: a consciência perdeu sua felicidade e nunca a alcançou, até porque, perder e nunca ter tido é a mesma coisa. Além do mais, ela precisa perder aquilo que nunca teve. Isto tudo apenas indica o estatuto ilusório da imediaticidade própria à eticidade em sua primeira manifestação. Pois a consciência ainda não sabe que é "pura singularidade para si", ou seja, ela ainda não é reconhecida enquanto consciência-de-si. 
ele [o espírito] sua vida essencial; está também consciente dessa perda e da finitude que é seu conteúdo. [Como o filho pródigo], rejeitando os restos da comida, confessando sua abjeção e maldizendo-a, o espírito agora exige da filosofia não tanto o saber do que ele é, quanto resgatar por meio dela, aquela substancialidade e densidade do ser [que tinha perdido]" ${ }^{46}$

Décadas depois de Hegel, a sociologia de Durkheim e Max Weber constituirão quadros convergentes de caracterização da modernidade como era própria a um certo sentimento subjetivo de indeterminação resultante da perda de horizontes estáveis de socialização. A autonomização das esferas sociais de valores na vida moderna, assim como a erosão da autoridade tradicional sedimentada em costumes e hábitos ritualizados, teria produzido uma perda de referências nos modos de estruturação das relações a si, uma problematização sem volta da espontaneidade de sujeitos agentes. ${ }^{47}$ A partir de então, o sujeito só pode aparecer como: "esta noite, este nada vazio que contém tudo na simplicidade desta noite, uma riqueza de representações, de imagens infinitamente múltiplas, nenhuma das quais lhe vem precisamente ao espírito, ou que não existem como efetivamente presentes [...] É esta noite que descobrimos quando olhamos um homem nos olhos, uma noite que se torna terrível, é a noite do mundo que se avança diante de nós". ${ }^{48}$

No entanto, Hegel não está disposto a se contentar com diagnósticos sócio-históricos. Ele quer fornecer o fundamento ontológico da situação histórica própria à modernidade, como se tal perda de horizontes estáveis não fosse apenas o resultado da contingência de processos históricos, mas fosse a realização de um destino marcado com a necessidade do que tem dignidade ontológica. Para tanto, Hegel precisa de uma noção de individualidade como aquilo que é habitado por uma potência de indeterminação, como aquilo que não se submete integralmente à determinação identitária da unidade sintética de um Eu. A teoria do desejo como falta, ou ainda, como negatividade que impulsiona o agir, forneceria a Hegel este fundamento ontológico procurado.

46 HEGEL. Fenomenologia do Espírito, p. 24.

47 E não é por acaso que todos os dois pensem tais fenômenos através da modificação do sentido sociológico da confrontação com a morte. A este respeito basta lembrar de Max Weber, para quem: "a vida individual do homem civilizado, colocada dentro de um progresso infinito, segundo seu próprio sentido imanente, jamais deveria chegar ao fim; pois há sempre um passo à frente do lugar onde estamos, na marcha do progresso. E nenhum homem que morre alcança o cume que está no infinito. Abraão, ou algum camponês do passado, morreu 'velho e saciado de vida', por que estava no ciclo orgânico da vida [...] O homem civilizado, colocado no meio do enriquecimento continuado da cultura pelas idéias, conhecimento e problemas, pode 'cansar-se da vida', mas não 'saciar-se dela'" (WEBER. Ensaios de sociologia, p. 166).

48 HEGEL. JenaerPhilosophie, p. 13. 
Ou seja, a falta aqui é, na verdade, o modo de descrição de uma potência de indeterminação e de despersonalização que habita todo sujeito.

Por sua vez, esta potência de indeterminação é um outro nome possível para aquilo que Hegel compreende por infinitude, já que o infinito é o que demonstra a instabilidade e a inadequação de toda determinação finita. O que não poderia ser diferente, pois, para Hegel, infinito é aquilo que porta em si mesmo sua própria negação e que, ao invés de se autodestruir, conservase em uma determinidade que nada mais é que a figura da instabilidade de toda determinidade. Daí porque ele podia afirmar, em uma frase-chave: "A infinitude, ou essa inquietação absoluta do puro mover-se-a-si-mesmo, faz com que tudo o que é determinado de qualquer modo - por exemplo, como ser - seja antes o contrário dessa determinidade". 49

Percebe-se claramente aqui que o conceito de infinitude é construído a partir da noção de contradição. Lembremos da definição de contradição fornecida por Kant: "O objeto de um conceito que se contradiz a si mesmo é nada, porque o conceito nada é o impossível, como, por exemplo, a figura retilínea de dois lados (nihil negativum)" ${ }^{50}$ Ou seja, a contradição é um objeto vazio sem conceito, já que não há representação possível quando tenho duas proposições contrárias aplicadas ao mesmo objeto, como no caso de uma figura que, ao mesmo tempo, é retilínea e tem dois lados. Hegel não quer pensar uma figura retilínea de dois lados, mas quer insistir que há objetos que só podem ser apreendidos através da aplicação de duas proposições contrárias, de duas séries divergentes. Isto talvez nos demonstre como a infinitude não é simplesmente uma estratégia astuta de desqualificação do sensível, mas é o fundamento que permite a crítica da submissão do sensível à gramática da finitude.

No entanto, como o sujeito é essencialmente locus de manifestação da infinitude, podemos dizer que o vocabulário da negatividade do desejo serve para salientar a natureza de inadequação entre as expectativas de reconhecimento de sujeitos e as possibilidades disponíveis de determinação social de si. ${ }^{51}$ Pois se trata de afirmar que a positividade da realidade reificada

49 HEGEL. Fenomenologia do Espírito, p. 116.

50 KANT. Crítica da razão pura, B348.

51 Monique David-Ménard, em um texto maior sobre a crítica à noção de desejo como falta, lembra como a psicanálise é tributária da idéia de que: "há uma verdade na experiência de uma inadequação do objeto pulsional à satisfação pulsional que um sujeito persegue". Isto obrigaria a filosofia a repensar: "a idéia medieval de que a verdade é a adequação do conceito e do objeto, assim como a idéia spinozista de que um pensamento verdadeiro desdobra suas determinações de maneira imanente e na univocidade e que não há verdade possível da inadequação" (DAVID-MĖNARD. Deleuze et la psychanalyse, p. 22). No entanto, esta inadequação não poderia ser pensada a partir de uma "lógica da negação" aplicada ao desejo. Pois esta lógica seria dependente do quadro de oposição entre o universal e o particular, onde 
com suas representações finitas estabeleceu-se de maneira tão forte como "representação natural do pensar" que apenas um esforço de negação pode romper tal círculo de alienação. Ou seja, o vocabulário da negatividade nada tem a ver com formas de julgamento resignado da vida, como se a vida precisasse ser desvalorizada enquanto espaço da finitude, como quer Lebrun. ${ }^{52}$ Ao contrário, ele é fruto da consciência do descompasso entre modos de determinação da vida social e as potencialidades da vida que realizou seu destino como Espírito.

De qualquer forma, Hegel acharia simplesmente incorreta esta maneira tão própria a nós, contemporâneos do pós-estruturalismo, de contrapor a negatividade do desejo à positividade de uma potência que se expressa de maneira imanente, tal como a relação entre a substância spinozista e seus modos. Pois, de uma certa perspectiva, o desejo é sempre destrutivo (ele sempre afirma sua inadequação em relação às determinações finitas) e, de outra, ele sempre é produtivo (sua verdade é afirmar-se como vontade livre que constitui quadros institucionais para seu reconhecimento através da relações de trabalho e linguagem). Hegel era tão cônscio dessa imbricação entre negatividade e produtividade que, ao falar da necessidade do terror revolucionário enquanto experiência histórica de internalização da negatividade que devasta toda determinação fenomenal, escreverá:

Mas, por isso mesmo, a vontade universal forma imediatamente uma unidade com a consciência-de-si, ou seja, é o puramente positivo porque é o puramente negativo; e a morte sem sentido, a negatividade do Si não-preenchido, transforma-se no conceito interior, em absoluta positividade..$^{53}$

\section{O caráter formador do "puro terror do negativo"}

Este é o pano de fundo adequado para a reflexão sobre a confrontação com a morte no trajeto de formação da consciência-de-si. Notemos, inicialmente, uma conseqüência maior. Se é verdade que Hegel é animado por uma teoria do desejo dessa natureza, então o conflito produzido pelo desejo, conflito que

o particular aparece como negativo que excede o universal. Mas poderíamos dizer que, ao menos no caso de Hegel, como se trata de pensar um conceito de infinitude ou de determinação infinita, a lógica da negação não é uma lógica da oposição ou da contrariedade, mas da negação determinada (para uma diferença entre oposição e negação determinada, remeto ao meu SAFATLE. Linguagem e negação: sobre as relações entre ontologia e pragmática em Hegel. Revista Dois Pontos, p. 124-167).

52 Ver: LEBRUN. L'envers de la dialectique, p. 222.

53 HEGEL. Fenomenologia do Espírito II, p. 100. 
aparece enquanto motor da DSE, não pode ser a mera colisão entre sistemas particulares de interesses de duas consciências distintas, como querem comentadores como Terry Pinkard e Jürgen Habermas. ${ }^{54}$ Conflito através do qual Eu procuro dominar o outro através da submissão do seu sistema de valoração e interesse à perspectiva própria ao meu sistema, onde Eu procuro submeter o desejo do outro ao meu desejo. Ao contrário, se Hegel pode afirmar que a formação para a vontade livre e universal passa pela submissão a um senhor, é porque este senhor não pode simplesmente representar uma outra determinação particular de interesse.

Se voltarmos os olhos à DSE, veremos Hegel insistindo que, após a luta por reconhecimento, a essencialidade do escravo parece estar depositada no senhor. É ele quem domina o seu fazer consumindo o objeto de seu trabalho. O escravo vê assim seu fazer como algo estranho. No entanto, Hegel insiste que este estranhamento pode significar elevação para além da particularidade, já que: "Enquanto o escravo trabalha para o senhor, ou seja, não no interesse exclusivo da sua própria singularidade, seu desejo recebe esta amplitude que consiste em não ser apenas o desejo de um este, mas de conter em si o desejo de um outro". ${ }^{55}$ Ter seu desejo vinculado ao desejo de um outro, entretanto, não nos fornece a universalidade do reconhecimento almejado pela consciência. Para que esse vínculo não seja simples submissão, faz-se necessário que esse outro tenha algo da universalidade incondicional do que é essencial, que ele seja um "senhor absoluto", cuja internalização me leva a ser reconhecido para além de todo e qualquer contexto. É tendo esse problema em vista que devemos interpretar a afirmação central:

Só mediante o pôr a vida em risco, a liberdade se conquista e se prova que a essência da consciência-de-si não é o ser, nem o modo imediato como ela surge, nem o seu submergir-se na expansão da vida, mas que nada há para a consciência que não seja para ela momento evanescente (verschwindendes Moment); que ela é somente puro ser-para-si. O indivíduo que não arriscou a vida pode ser bem reconhecido como pessoa (Person), mas não alcançou a verdade desse reconhecimento como uma consciência-de-si independente. ${ }^{56}$

Se a confrontação com a morte é condição para a conquista da liberdade, é porque a morte é figura privilegiada desta universalidade incondicional e absoluta que, por ser incondicional e absoluta, manifesta-se como negação

54 Ver PINKARD. Hegel's phenomenology: The sociality of reason; e HABERMAS. Caminhos da destranscendentalização. In: Verdade e justificação.

55 HEGEL. Enciclopédia das ciências filosóficas, v. 3, § 433.

56 HEGEL. Fenomenologia do Espírito, p. 128-129. 
de tudo o que é condicionado e finito. Devemos levar isso em conta quando encontramos Hegel dizendo:

A submissão (Unterwerfung) do egoísmo do escravo forma o início da verdadeira liberdade dos homens. A dissolução da singularidade da vontade, o sentimento de nulidade do egoísmo, o hábito da obediência (Gehorsams) é um momento necessário da formação de todo homem. Sem ter a experiência deste cultivo (Zucht) que quebra a vontade própria (Eigenwillen), ninguém advém livre, racional e apto a comandar. E para advir livre, para adquirir a aptidão de se auto-governar, todos os povos tiveram que passar pelo cultivo severo da submissão a um senhor. ${ }^{57}$

Afirmações desta natureza servem a vários mal-entendidos. Hegel não está dizendo que a liberdade é apenas o nome que damos para uma vontade construída a partir da internalização de "dispositivos disciplinares” travestidos de práticas de autocontrole. Não é qualquer submissão a um senhor que produz a liberdade, mas apenas a um senhor que seja capaz de realizar exigências incondicionais de universalidade. Isto nos explica porque, para Hegel, as grandes individualidades capazes de submeter um povo produzem, necessariamente, o sentimento de que o trabalho do Espírito é sem medida comum com toda e qualquer política finita, com todo cálculo utilitarista baseado em "meu" sistema de interesses egoístas. Por sinal, a maior de todas as ilusões consiste exatamente em ver na crítica hegeliana do egoísmo uma estratégia astuta de esvaziamento do particular. Hegel pode criticar o egoísmo porque não há nenhuma individualidade neste "ego", já que não há nada de individual no interior de um sistema de interesses construído, na verdade, a partir de identificações e internalização de princípios de conduta vindos de uma outra consciência determinada. ${ }^{58}$ Por isso, a "dissolução da singularidade da vontade" pode aparecer como "liberação".

Lebrun serve-se dessas características da filosofia hegeliana para afirmar que a formação da consciência-de-si é apenas a dissolução de um indivíduo definido como o que se anula, renúncia incessante de si, ascese permanente. Pois: "ganhar uma determinação acaba sempre por ser renúncia a uma diferença que me individualizava, advir um pouco mais meu ser verdadeiro na medida em que sou um pouco menos meu ego". ${ }^{59}$ Neste sentido, tremer diante do mestre absoluto seria tomar consciência da impotência de princípio

57 HEGEL. Enciclopédia das ciências filosóficas, § 435.

58 Esta intuição hegeliana recebeu uma confirmação material através da psicanálise lacaniana e sua descrição da gênese do Eu através da internalização da imagem de um outro que tem a função de tipo ideal de conduta e de orientação do desejo. A este respeito, remeto ao capítulo "Desejo sem imagens" (In: SAFATLE. Lacan).

59 LEBRUN. L'envers de la dialectique, p. 100. 
que representa a singularidade natural. Como se a liberação hegeliana fosse um passe de mágica no qual o sentimento de fraqueza se transforma em legitimação da incapacidade de resistir. Assim: "em troca de seus sofrimentos, é o gozo do universal que se oferece à consciência - belo presente ..." ${ }^{60}$ Não estamos muito longe de Deleuze vendo a dialética hegeliana como "idéia do valor do sofrimento e da tristeza, valorização das 'paixões tristes' como princípio prático que se manifesta na cisão, no dilaceramento". ${ }^{61}$

No entanto, podemos fornecer uma interpretação diferente. Basta estarmos mais atentos para o sentido que Hegel dá a esta despossessão de si produzida pela internalização da morte como senhor absoluto. Neste contexto, a morte não é destruição simples da consciência, não é um simples despedaçar-se (zugrunde gehen), mas é modo de ir ao fundamento (zu Grund gehen). Pois a confrontação com a morte é experiência fenomenológica que visa exprimir o acesso ao caráter inicialmente indeterminado do fundamento, que visa exprimir como: "A essência, enquanto se determina como fundamento, determina-se como o não-determinado (Nichtbestimmte) e é apenas a superação (Aufheben) de seu ser determinado (Bestimmtseins) que é seu determinar". ${ }^{62} \mathrm{O}$ que pode ser entendido da seguinte maneira: a indeterminação do fundamento vem do fato de ele servir de substrato comum entre determinações opostas, daí porque Hegel poderá afirmar que o fundamento implica a unidade entre a identidade e a diferença (die Einheit der Identität und des Unterschiedes). Mas sendo o Eu o princípio sintético que fornece o fundamento da experiência, assim como o princípio de ligação e unidade que determina o modo de articulação entre o fundamento e aquilo que ele funda, então pensar a verdadeira essência do fundamento como o que tem seu ser em um outro (sein Sein in einen Anderen hat) exige a confrontação com um estado de diferenças não submetidas à forma do $\mathrm{Eu} .{ }^{63}$

Demoremo-nos um pouco mais neste ponto. Sabemos que fundar é determinar o existente através da sua relação a um padrão que me permite orientar no pensamento. Por exemplo, ao mobilizar estruturas categoriais como a causalidade, a modalidade para assegurar a inteligibilidade dos fenômenos, determino a forma do existente. A partir deste recurso à forma como fundamento, posso garantir o critério do verdadeiro e do falso, do

60 Idem, p. 211

61 DELEUZE. Nietzsche et la philosophie, p. 224.

62 HEGEL. Wissenschaft der Logik II, p. 81.

63 Longuenesse compreendeu isto bem ao afirmar que, para Hegel: "O fundamento é o herdeiro da unidade de apercepção da Crítica da razão pura” (LONGUENESSE. Hegel et la critique de la métaphysique, p. 111). 
correto e do incorreto, do adequado e do inadequado. Mas a aplicação de todas estas estruturas aos fenômenos depende de uma decisão prévia e tácita sobre princípios lógicos gerais de ligação e unidade capazes de constituir objetos da experiência e fundar proposições de identidade e diferença. Esses princípios de ligação (Verbindung) e unidade são derivados do Eu como unidade sintética de apercepções, que aparece assim como o verdadeiro fundamento das determinações. No entanto, a problematização de tais princípios é o verdadeiro objeto da dialética. Por exemplo, quando Hegel constrói um witz ao dizer que, para a consciência, "o ser tem a significação do seu" (das Sein die Bedeutung das Seinen hat), ${ }^{64}$ ele tem em vista o fato de que ser objeto para a consciência significa estruturar-se a partir de um princípio interno de ligação e unidade que é modo de a consciência apropriar-se do mundo, constituir o mundo a partir de sua imagem, o que permite a Hegel ignorar a relevância das distinções kantianas entre receptividade e espontaneidade.

A dialética precisa, pois, aceder a um fundamento não mais dependente da forma auto-idêntica do Eu, o que é possível através da superação dos modos naturalizados de determinação, através da fragilização das imagens de mundo que orientam e constituem nosso campo estruturado de experiências. Tal fragilização é descrita fenomenologicamente por Hegel através da angústia e da confrontação com a morte.

Vemos assim como a confrontação com a morte permite à consciênciade-si compreender o Espírito como aquilo que se expressa na multiplicidade de suas determinações fragilizando-as todas, levando-as a confrontar-se com uma potência do pré-pessoal e do indeterminado que nos permite, inclusive, recompreender o que vem a ser a diferença. A diferença não será aquilo que determina a distinção entre entidades conceitualmente articuladas, como Deleuze imputa a Hegel. A diferença em Hegel é esta potência interna da in-diferença que corrói toda determinação. Ela será esta expressão do ser que nos leva a afirmar, com Scott Fitzgerald, que: "toda vida é um processo de demolição". Demolição que ocorre quando desvelamos esta "franja de indeterminação da qual goza todo indivíduo". ${ }^{65}$ Não se trata exatamente de um ganho de determinação e positividade, mas da assunção de um risco vinculado à confrontação com aquilo que se coloca enquanto puramente indeterminado. Nestas condições, submeter-se a um Senhor absoluto que dissolve tudo aquilo que parecia fixo e determinado nada tem a ver com uma dinâmica psicológica da resignação, do ressentimento ou da necessidade da repressão. 


\section{A determinação pelo trabalho}

Para finalizar, devemos comentar o ponto essencial que irá estabilizar esta dialética. Pois a angústia sentida pela consciência escrava não fica apenas em uma:

universal dissolução em geral, mas ela se implementa efetivamente no servir (Dienen). Servindo, suprime (hebt) em todos os momentos tal aderência ao Dasein natural e trabalhando-o, o elimina. Mas o sentimento da potência absoluta em geral, e em particular o do serviço, é apenas a dissolução em si e embora o temor do senhor seja, sem dúvida, o início da sabedoria, a consciência aí é para ela mesma, mas não é ainda o ser para-si; ela porém encontra-se a si mesma por meio do trabalho. ${ }^{66}$

Hegel fará então uma gradação extremamente significativa que diz respeito ao agir da consciência nas suas potencialidades expressivas. Hegel fala do serviço (Dienen), do trabalho (Arbeiten) e do formar (Formieren). Esta tríade marca uma realização progressiva das possibilidades de autoposição da consciência no objeto do seu agir. O serviço é apenas a dissolução em si (Auflösung an sich) no sentido da completa alienação de si no interior do agir, que aparece como puro agir-para-um-outro e como-um-outro. O trabalho implica uma autoposição reflexiva de si. No entanto, sabemos que Hegel não opera com uma noção expressivista de trabalho que veria sua realização mais perfeita em uma certa compreensão do fazer estético como manifestação das capacidades expressivas dos sujeitos. A consciência que trabalha não expressa a positividade de seus afetos em um objeto que circulará no tecido social. O trabalho não é a simples tradução da interioridade na exterioridade. De uma certa forma, a categoria hegeliana de trabalho é inicialmente uma defesa contra a angústia diante da negatividade da morte ou, ainda, uma superação dialética da angústia, já que ele é autoposição de uma subjetividade que sentiu o desaparecer de todo vínculo imediato ao Dasein natural, que sentiu o tremor da dissolução de si. Lembremos desta afirmação central de Hegel:

O trabalho é desejo refreado (gehemmte Begierde), um desvanecer contido, ou seja, o trabalho forma. A relação negativa para com o objeto toma a forma do objeto e permanece, porque justamente o objeto tem independência para o trabalhador. Esse meio-termo negativo ou agir formativo é, ao mesmo tempo, a singularidade, ou o puro-ser-para-si da consciência que agora no trabalho se transfere para fora de si no elemento do permanecer; a consciência trabalhadora chega assim à intuição do ser independente como intuição de si mesma [...] no formar da coisa, torna-se objeto para o escravo sua própria negatividade. ${ }^{67}$ 
Por refrear o impulso destrutivo do desejo em seu consumo do objeto, o trabalho forma, no sentido de permitir a auto-objetivação da estrutura da consciência-de-si em um objeto que é sua duplicação. Sua função será, pois, realizar, ainda que de maneira imperfeita, o que o desejo não era capaz de fazer, ou seja, permitir a autoposição da consciência-de-si em suas exigências de universalidade, já que o trabalho está organicamente vinculado a modos de interação social e de reconhecimento.

O giro dialético consiste em dizer que a alienação no trabalho, a confrontação tanto com o agir enquanto uma essência estranha, enquanto agir para-um-Outro absoluto, quanto com o objeto enquanto aquilo que resiste ao meu projeto (experiência de resistência que será fundamental para alguém como Adorno desenvolver a idéia de dialética como primado do objeto) tem caráter formador por abrir a consciência à experiência de uma alteridade interna como momento fundamental para a posição da identidade. Daí porque Hegel afirma que tanto o medo quanto o formar são dois momentos necessários para este modo de reflexão que é o trabalho. Hegel não teme afirmar que o formar sem o medo absoluto fornece apenas um sentido vazio, pois sua forma ou negatividade não é "a negatividade em si” (Negativität an sich). Através do trabalho, o lugar do sujeito como fundamento pode ser compreendido como negação em si: conseqüência necessária de uma filosofia do sujeito onde "sujeito" não é mais do que o nome do caráter negativo do fundamento.

Afirmar que há um caráter negativo do fundamento significa, entre outras coisas, que a relação ao existente não é a repetição do que está potencialmente posto no fundamento, mas que a própria determinação do existente não pode mais ser pensada a partir do paradigma da subsunção simples do caso à norma. Ela exige compreender que não há determinação completa no sentido de identidade completa entre a determinação e o fundamento. É isto que a consciência-de-si descobrirá pelas vias do trabalho.

Notemos, por fim, que temos uma explicação para o fato de, na Fenomenologia do Espírito, o trabalho não nos colocar no caminho da "institucionalização da identidade do Eu". ${ }^{68} \mathrm{Ou}$ seja, contrariando o que poderíamos esperar, o trabalho não abre uma dinâmica de reconhecimento que se realizará na regulação jurídica das minhas relações com o outro através da assunção de meus direitos como sujeito que colabora com a riqueza (Vermögen) social. Ou ainda, ele faz isto, mas à condição de recomprendermos completamente o que entendíamos por "identidade", "direitos", "sujeito". 
Isto porque Hegel está mais interessado no fato de o trabalho aparecer como modo de posição de uma negatividade com a qual o sujeito se confrontou ao ir em direção a uma potência de indeterminação cuja assunção é condição para a consciência-de-si "viver no universal". Daí podemos derivar o problema maior da modernidade, ao menos segundo Hegel; problema este que está na base da sua filosofia do direito, a saber, como viabilizar o reconhecimento institucional de sujeitos pensados enquanto modos singulares de confrontação com o que se oferece como indeterminado? Pois não é a indeterminação que produz sofrimento social, mas a incapacidade de as estruturas institucionais e os processos de interação social reconhecerem sua realidade fundadora da condição existencial de todo e qualquer sujeito. Se tais estruturas forem capazes de fornecer o delineamento de processos de reconhecimento da potência de indeterminação que habita todo sujeito, então talvez possamos encontrar o caminho para recuperar um conceito renovado de amor enquanto horizonte regulador de práticas de interação social. Mas, de uma maneira que ainda não está clara, este amor deverá portar experiências de despersonalização e infinitude que Hegel vincula inicialmente à confrontação com a morte. Por isso, não seria apenas licença poética dizer, parafraseando Fassbinder, que ele é a promessa de um amor mais frio que a morte.

\section{Referências}

ADORNO, Theodor. Negative Dialektik. Frankfurt: Suhrkamp, 1973.

ARANTES, Paulo. Um Hegel errado mas vivo. Revista Ide, São Paulo, n. 21, p. $72-$ 79, 1991.

DAVID-MÉNARD. Deleuze et la psychanalyse. Paris: PUF, 2005.

DELEUZE, Gilles. Différence et répétition. 10 éd. Paris: PUF, 2000.

DELEUZE, Gilles. Nietzsche et la philosophie. $5^{\mathrm{e}}$ éd. Paris: PUF, 2005.

DELEUZE, Gilles; GUATTARI, Félix. L'anti-CEdipe. Paris: Minuit, 1969.

HABERMAS, Jürgen. O discurso filosófico da modernidade. Lisboa: Dom Quixote, 1988.

HABERMAS, Jürgen. Verdade e justificação. Belo Horizonte: Loyola, 2004.

HABERMAS, Jürgen. Técnica e ciência como ideologia. Lisboa: Edições 70, 2007.

HONNETH, Axel. Lutte pour reconnaissance. Paris: Cerf, 2000.

HONNETH, Axel. Sofrimento de indeterminação. São Paulo: Esfera Pública, 2005.

HEGEL, G. W. F. Diferença dos sistemas filosóficos de Fichte e Schelling. Lisboa: Imprensa Nacional da Casa da Moeda, 2003.

HEGEL, G. W. F. Enciclopédia das ciências filosóficas. Belo Horizonte: Loyola, 1995. 3 v.

HEGEL, G. W. F. Enzyclopädie der philosophischen Wissenchaften im Grundisse. Frankfurt: Suhrkamp, 1988. 
HEGEL, G. W. F. Fenomenologia do Espírito. Petrópolis: Vozes, 1992.

HEGEL, G. W. F. Phänomenologie des Geistes. Hamburgo: Felix Meiner, 1988.

HEGEL, G. W. F. Grundlinien der Philosophie des Recht. Frankfurt: Suhrkamp, 1996.

HEGEL, G. W. F. Wissenschaft der Logik II. Frankfurt: Suhrkamp, 1986.

HYPPOLITE, Jean. Gênese e estrutura da Fenomenologia do Espírito. São Paulo:

Discurso Editorial, 1999.

LEAR, Jonathan. Open minded: working out the logic of the soul. Harvard University Press, 1998.

LEBRUN, Gerard. L'envers de la dialectique. Paris: Seuil, 2004.

LONGUENESSE, Béatrice. Hegel et la critique de la métaphysique. Paris: Vrin, 1981.

KANT, Immanuel. Crítica da razão pura. Lisboa: Fundação Calouste Gulbenkian, 1980.

MALABOU, Cathérine. L'avenir de Hegel: plasticité, temporalité, dialectique. Paris: Vrin, 1996.

MORTLEY, Robert. Désir et différence dans la tradition platonicienne. Paris: Vrin, 1988.

PIPPIN, Robert. Hegel's idealism: The satisfaction of self-consciousness. Cambridge University Press, 1989.

PINKARD, Terry. Hegel's phenomenology: The sociality of reason. Cambridge University Press, 1994.

PLATÃO. Le banquet. In: CEuvres Complètes. Paris: Gallimard, 1950.

SAFATLE, Vladimir. Lacan. São Paulo: Publifolha, 2007.

SAFATLE, Vladimir. Linguagem e negação: a ontologia hegeliana como pragmática. Revista Dois Pontos, São Carlos; Curitiba, v. 3, n. 1, p. 124-167, 2006.

SIEP, Ludwig. Der Kampf um Anerkennung. Zur Auseinandersetzung Hegels mit Hobbes in den Jenaer Schriften. In: Hegel-Studien. Bonn, 1974. Bd. 9, p. 155-207.

TAYLOR, Charles. Hegel e a sociedade moderna. São Paulo: Loyola, 2005.

WEBER, Max. Ensaios de sociologia. 5. ed. São Paulo: LTC, 2002.

WILLIAMS, Robert. Hegel's ethic of recognition. University of California Press, 1998. 